\title{
An Investigation of Students Autonomous Learning Performance during Covid-19 outbreak: A Case Study
}

\author{
Made Wahyu Mahendra ${ }^{1}$ \\ ${ }^{1}$ Universitas Hindu Negeri I Gusti Bagus Sugriwa, Indonesia \\ (madewahyumahendra@uhnsugriwa.ac.id)
}

\begin{abstract}
Covid-19 outbreak has brought a great disruption to instructional process. Needless to say, the goal of instructional process needs to shift from student centred learning to promoting learner autonomy. Yet, it is important to conduct a study which learn the students' capacity to be autonomous. This present study aims at investigating learners' autonomous learning capacity during this outbreak. The researcher employed a mix method design where the data obtained were presented in both quantitative and qualitative perspectives. There are total 30 higher education students chosen to be the subjects of the present study. The data were gathered through different instruments; questionnaire and semi structured interview. The questionnaire comprises five major aspects in measuring learners' capacity in autonomous learning. In order to achieve the credibility of the data, the researchers' employs triangulation of data. The results of the study showed that learners have the capacity of autonomous learning to some extent. Learners are quite self-directed in the aspects of defining content and progression, monitor the procedure of acquiring knowledge, and doing selfevaluation. Meanwhile, the aspects of setting objectives and selecting method to learn need to be improved. The findings imply that optimization of learning is a must despite all boundaries that challenge both learners and educators.
\end{abstract}

Keywords: autonomous learning; learning capacity; Covid-19 outbreak.

In the early 2020, Covid-19 has gripped more than 215 countries. This fast spread of covid-19 outbreak has totally changed the educational system in many countries, including Indonesia. Additionally, it forces all educational institutions to minimize face-to face instructional process, rather change at once to remote learning (Abidah, Hidaayatulaah, Simamora, Fehabutar, \& Mutakinati, 2020). The government, as stated by Zaharah, Kirilova, \&
Windarti (2020) implements remote teaching and learning to diminish the rapid spread of coronavirus in schools and higher educations. Moreover, all educational institutions are prompted an unscheduled close of their work (Basilaia \& Kvavadze, 2020).

A disruption to online learning also leads to several major challenges to face. According to Dubey \& Pandey (2020) some of the major problems are lack of adequate 
infrastructure, access to technology, and paradigm shift to digital learning. Lack of adequate infrastructure has always become the cause of improper functional implementation. Ironically, this happened in a number of places from elementary school to higher education. in Indonesia, this major problem has been found from a number of studies such as in Aji (2020). He finds out that one of the cause is the expensive rate to be equipped with this supportive facility. This also make students to adapt more slowly than expected (Purwanto, et al., 2020). Additionally, Alvarez (2020) adds that lack of infrastructure can be in a form of poor internet connection which further lead to struggles and discomfort to learn.

It also results in several consequences that both teachers and students need to carry, particularly in higher level education. Nugroho et al. (2021) highlight some of challenges faced by teachers in this pandemic era. Firstly the inescapable shift from face to face to total online learning has brought a shock to teachers. They need to think quickly of an effective method to teach, how to create classroom interaction, and also how to assess students fairly. Most recently, Scherer et al. (2021) emphasize two main condition that teachers need to overcome, they are personal readiness where it deals with teachers professionalism and contextual readiness that deals with pedagogical competence of teachers.

From higher education students' perspective, the challenge they mostly face is building interest to a total online learning since they are not accustomed to learning with online devices (Mishra et al., 2020). This also leads to problem in communication since they need many factors to have an intense communication online. Muthuprasad et al (2021) add that in relation to being autonomous, higher education students need to take into account of two aspects. The comfort with e-learning measures the learners' readiness to learn online, while the other aspect is self-management. In this regard, students are required to be able demanding themselves to progress forward rather than only waiting for instruction from their lecturers.

Access to technology is closely related to the questions of how far teachers and lecturers are able to adopt technology for constructivism. It is undeniably true that the advanced technology used has eased students to get access to direct answer to their task, yet their cognitive development is disputable. This is supported by Onyema, et al. (2020) who state that interrupted learning during this pandemic has deprived students from opportunities for growth and development. Lastly, a shift in paradigm means a change in thinking process of the learner due to sudden adoption to remote learning. Those students who are accustomed to classroom interaction, classroom project, will find it difficult to suddenly change their mindset. This is supported by Gillett-Swan (2017) who stresses that the barriers to participations that students may encounter is how to optimize collaborative learning, group presentations, and knowing how they are assessed through distance learning. Furthermore, a sudden change in ways of learning can bring personal issue such as anxiety to use technology, being out of comfort zone, and inequity in assessment. Specific to Indonesian perspective, the challenge is even higher. The requirement to adopt technology to be implemented is blocked by the actual condition where Indonesia is still faced by the fact that it has lack of ICT infrastructure, lecturer's competencies, technical skills, and ICT literacy (Aini et al., 2020).

There are evidently solutions to these problems. Citing the fact stated by Dhawan (2020) that online teaching is no more an option, but a necessity, educators are eager to customize their instructional teaching method. Thus, a number of experts have provided options to remote teaching method such as using animations with feedback (Brasier, Melville, Hershock, \& Rule, 2019), video lectures (Wang, $\mathrm{Pi}, \& \mathrm{Hu}, 2018$ ), and online formative assessment in response to students doubt about how they will be assessed online 
(Mclaughlin, 2017).

On the other hand, promoting students autonomous learning is hardly taken into account by educators during this outbreak. According to Üstünlüoğlu (2009), even though new technique, skills, media emerged to enhance language learners to achieve their goal, there is always a tendency to see learners as passive receivers of information and as individuals who are unable to be responsible with their own learning progress and control their ways of learning. In fact, helping learners to become more conscious of their learning must be educators' concern.

The basic principle of autonomous learning is to help learners achieve their objective by using skills and continuous learning (Littlewood, 1996). Though it means that learners will take charge of their own learning, that does not mean that assistance and help is fully neglected from learners. This is due to the fact that autonomous learning is not inborn, but a natural tendency (Masouleh \& Jooneghani, 2012). Accordingly, Benson (2001) argues that autonomy is attributive to language learners so it can be taught.

Specific to English language teaching, autonomous learning is considered as capacity, attribute, and attitude with different forms in different context, different levels as every learner is unique to their own characteristics. It is also noted that learner autonomy always prevails between total self-directed learning and traditional or conventional learning. Therefore, it is essential to determine a framework in order to assess to what extent that the language learners are autonomous. Holec (1980) divides individual's ability to make decision in learning into five developmental components as following; 1) Establishing the objectives. 2) Deliniating the contents and progressions. 3) Determining methods and techniques to be used. 4) Controlling the scheme of acquisition. 5) evaluating the acquisition

Based on the aforementioned explanation, this study focuses on investigating the extent of language learners' autonomy by building the framework based on Holec (1980) five developmental components. This study also gives detail explanation on how autonomous the learners are to learn language during this outbreak remotely. Furthermore, this study is expected to contribute to the board of knowledge in relation to promoting learner autonomy starting from their capacity.

\section{The Concept of Learning Autonomy}

The concept of learning autonomy in the past twenty years has undergone several changes on its domain in foreign language education. The debate is aroused by different perspective on how to promote learning autonomy as well as the direction of the research (Finch, 2000; Holec, 1981; Little, 1991). The first view sees the development of learner autonomy as a primary requisite of learning beyond school (Benson, 2001). On the other hand, the other focuses on how to solve the secret of the good language learner by emphasizing learner strategies and the notion of learning (Finch, 2000).

Therefore, learner autonomy has been defined differently and in a number of ways in relation to language learning. The most common definition can be derived from Holec's view which is the ability to take charge of one's own learning. Dafei (2007) adds that learners can be defined as autonomous if they are responsible with the five aforementioned aspects proposed by Holec. According to Genc (2015), these five aspects are interrelated to four co-occuring behavioral syndrome factors namely (a) desire, (b) resourcefulness, (c) initiative, and (d) persistence.

Desire plays an important role in promoting students' autonomous learning since it is the starting point to move on to the others factors. According to Liu (2015) a learner with full of desire will expend effort to the goals s/he set, create enjoyment during the progress, and adapt to learning situation. Meanwhile Meyer (2001) determine three elements to help learners having higher desire 
to learn, they are basic freedoms (expression and circumstance understanding), power management (identity, growth) and change skills (the ability to change behaviors).

Furthermore, resourcefulness is learners' ability to seek for experience outside from his own knowledge to have a better understanding to a matter in order to achieve goals. According to Ponton \& Rhea (2006) resourcefulness is considered as an active approach fostered by desire to seek for more knowledge and solution. Genc (2015) adds that the autonomous learner will actively search for resources that are useful for him or her in the learning experience. Moreover, resourcefulness measures the degree to which a learner anticipates the benefits of learning, whether to prioritize learning over non-learning activities, and solving problems encountered that interfere learning desire (Ponton, 2018).

According to Gharti (2019), taking initiative means a process of learning where learners take actions with or without help of others, finding their learning goals, formulating them, identifying materials and resources for learning, and implementing appropriate strategies. It is necessarily to mention that self-efforts and self-initiative plays more in autonomous learning rather than asking support from others. Ni (2020) states that initiative comes from consciousness. The only time when learners are conscious they will realize the significance of their learning goals and actively taking actions to achieve them. The ability to take initiative will also lead to being responsible to the subject that they learn, carefully select information, and actively construct knowledge.

Persistence is defined as behavioral intentions of a learner to sustain their volition, self-regulation, and goal directedness (Myartawan, Latief, \& Suharmanto, 2013). Volition is related to how to be consistent in the intended behavior, while self-regulation is regulating the activities that fit in oneself and done as self-reflection. Lastly, goal directedness means perseverance to attain the set goals.

Autonomous learning is an important construction to be applied in language learning. There has seemingly a number of researchers who have proven the effectiveness of promoting learners' language learning autonomy, yet there has not been one investigating learners' autonomous learning condition during the pandemic. Thus, previous studies in relation to autonomous learning become powerful supportive sources to this present study.

Padmadewi (2016) for instance, she has major concerned on how language teachers should be able to promote learners autonomy in the classroom situation despite the potential owned by young lerners. This study has proven that several activities successfully promote learners autonomy such as the use of reading log where learners choose story books based on their interest, evaluate their own reading, and being given reward to maintain their selfregulated learning.

Tran \& Duong (2020) investigated learners' perception of factors influencing them to develop autonomy in learning. This is due to the researchers' perspective that learners nowadays have been equipped with advances technological tools like Facebook, twitter, YouTube. They also have freedom and openness to communicate with each other which further lead to independency in learning. Their finding showed there are three major factors that could either support or resist their autonomy development, namely personal, academic, and external.

The issue of fostering learner autonomy in higher education has also been raised by Xhaferi \& Xhaferi (2011). Their study views that there is higher demand for higher education learners to be more autonomous in their learning yet it still hard for lecturers to find effective ways to foster their autonomy. Their study reveals that making note and diary to keep checking to their learning progress is the most effective way to foster students learning autonomy. 
These aforementioned studies show us that investigating and promoting learner autonomy has become an appealing issue to discuss, even more in this outbreak situation. In the environment of remote learning for a long period of time, learners have no choice but to maintain the autonomy themselves since it is harder for teachers to control them like they do in classroom situation.

\section{Method}

This study employs a mixed method where the data are presented both quantitatively and qualitatively to explain and measure the autonomous learning capacity of the learners. There are 30 higher education learners selected as the participants of the study comprise of 18 females and 12 males. The selection of the subjects is based on some criteria constructed by the researcher. Firstly, the subjects must be an active higher education language learner. Secondly, they must be involved in remote teaching and learning process during this outbreak. Their willingness to participate is considered as the last criteria. There are several instruments used in this study. The researcher works as the main instrument. Also, questionnaire is utilized to sight information about learners' level of autonomous learning in this pandemic situation. It consists of 25 questions involving the five aspects measured in this study. The detail of the instruments can be explain as follows: (1) five items featuring learners' level of realization in regards to set objectives; (2) five items to evaluate learners level of understanding to define contents and progression; (3) five items to evaluate their ability to select methods used in learning; (4) five items to evaluate learners level of understanding to monitor the procedure of acquiring knowledge; and (5) five items to evaluate their ability to conduct selfevaluation. In addition to that, the researchers also conduct a semi opened interview to the subjects to support the data gathered from the questionnaire.

In order to get credible data, the researchers conduct data triangulation and member checks. The triangulation involves the data derived from questionnaire, interview, and researchers' interpretation to the gathered data. Meanwhile member check is done to see the consistency of data interpretation by working with some experts to check the credibility of the interpreted data.

\section{Results and Discussion}

This study intends to determine the autonomous learning capacity of EFL learners in higher education scope. The subjects of the study are required to fill in questionnaire and join a semi structured interview to support the primary data gathered from the questionnaire.

Table 1. Learners' response on ability to set objectives

\begin{tabular}{|c|c|c|c|c|c|}
\hline \multirow[t]{2}{*}{ Items } & \multicolumn{5}{|c|}{ Attitude } \\
\hline & $\begin{array}{l}\text { Strongly } \\
\text { agree }\end{array}$ & Agree & Moderate & Disagree & $\begin{array}{l}\text { Strongly } \\
\text { disagree }\end{array}$ \\
\hline I like my lecturer to set my learning goals & $20 \%$ & $44 \%$ & $23 \%$ & $13 \%$ & 0 \\
\hline $\begin{array}{l}\text { It is important to realize and make decision about } \\
\text { one's own learning in this pandemic }\end{array}$ & $17 \%$ & $63 \%$ & $20 \%$ & 0 & 0 \\
\hline $\begin{array}{l}\text { Effective language learners make decisions about } \\
\text { their own learning }\end{array}$ & $14 \%$ & $70 \%$ & $10 \%$ & $6 \%$ & 0 \\
\hline $\begin{array}{l}\text { I love to decide what to achieve even learning in } \\
\text { outbreak situation }\end{array}$ & $13 \%$ & $47 \%$ & $30 \%$ & $10 \%$ & 0 \\
\hline $\begin{array}{l}\text { It is me who needs to determine my own achieve- } \\
\text { ment }\end{array}$ & $27 \%$ & $53 \%$ & $17 \%$ & $3 \%$ & 0 \\
\hline
\end{tabular}


Table 2. Learners response on the ability to define content and progression

\begin{tabular}{|c|c|c|c|c|c|}
\hline \multirow[t]{2}{*}{ Items } & \multicolumn{5}{|c|}{ Attitude } \\
\hline & $\begin{array}{l}\text { Strongly } \\
\text { agree }\end{array}$ & Agree & Moderate & Disagree & $\begin{array}{l}\text { Strongly } \\
\text { disagree }\end{array}$ \\
\hline I need my lecturer's help every time & $20 \%$ & $27 \%$ & $20 \%$ & $33 \%$ & 0 \\
\hline $\begin{array}{l}\text { It is an important thing for me to see the progress I } \\
\text { make by myself }\end{array}$ & $33 \%$ & $67 \%$ & 0 & 0 & 0 \\
\hline $\begin{array}{l}\text { The lecturer should tell me every time I make prog- } \\
\text { ress and error via any media possible }\end{array}$ & $17 \%$ & $67 \%$ & $13 \%$ & $3 \%$ & 0 \\
\hline $\begin{array}{l}\text { I know which aspects of my translation I want to } \\
\text { improve }\end{array}$ & $13 \%$ & $43 \%$ & $37 \%$ & $7 \%$ & 0 \\
\hline $\begin{array}{l}\text { I regularly check my own progress in translation } \\
\text { using technologies that I equipped with }\end{array}$ & $20 \%$ & $40 \%$ & $33 \%$ & $7 \%$ & 0 \\
\hline
\end{tabular}

The results of the questionnaire are presented in the following sections.

\section{Learners' ability to set objectives}

The ability of learners to set objectives for their learning is crucial for next step. Table 1 shows us the learners ability to set their objectives.

The learners' response shows that they are well aware of the importance of how to make decision of their own learning in this pandemic. It is reflected by their answer that show $80 \%$ of them agree to the statement. They also indicate a will to be effective learners where $84 \%$ of them answer the statement by stating that they agree if effective learners need to make decision of their own learning. In addition, the majority of the subjects $(80 \%)$ also set their own achievement. However, they cannot neglect the fact that they still need lecturers during this pandemic to help them set their goals. Some of the subjects argue that they cannot set their goals fully themselves. It is shown in the data that $64 \%$ of the subjects still expect the lecturers to help them setting the learning goals.

This data is quite linear to results found in the interview. According to the subjects' responses, they need friends' and lecturers' help and support to determine goals of their learning. Even it is in the outbreak situation, it does not hinder them from being interested in the course subject. Moreover, some of the subjects also stated that learning remotely provides them with more sources and inspiration for their prospective undergraduate

Table 3. Learners' response on the ability to selecting method

\begin{tabular}{|c|c|c|c|c|c|}
\hline \multirow[t]{2}{*}{ Items } & \multicolumn{5}{|c|}{ Attitude } \\
\hline & $\begin{array}{l}\text { Strongly } \\
\text { agree }\end{array}$ & Agree & Moderate & Disagree & $\begin{array}{l}\text { Strongly } \\
\text { disagree }\end{array}$ \\
\hline $\begin{array}{l}\text { I need the lecturer to tell me what to do online to } \\
\text { help me learning }\end{array}$ & $40 \%$ & $53 \%$ & $3 \%$ & $3 \%$ & 0 \\
\hline $\begin{array}{l}\text { The lecturer plays the only role for me learning } \\
\text { during this outbreak }\end{array}$ & 0 & $53 \%$ & $30 \%$ & $17 \%$ & 0 \\
\hline I can find the best ways to learn translation myself & $10 \%$ & $43 \%$ & $40 \%$ & $7 \%$ & 0 \\
\hline $\begin{array}{l}\text { Outside from the online class, I practice translation } \\
\text { by myself using technologies }\end{array}$ & $27 \%$ & $57 \%$ & $16 \%$ & 0 & 0 \\
\hline $\begin{array}{l}\text { I think it is enough that the lecturer gives me task } \\
\text { and do not need to do more on my own }\end{array}$ & $10 \%$ & $30 \%$ & $23 \%$ & $27 \%$ & $10 \%$ \\
\hline
\end{tabular}


Table 4. Learners' response to monitor the procedure of acquiring knowledge

\begin{tabular}{|c|c|c|c|c|c|}
\hline \multirow[t]{2}{*}{ Items } & \multicolumn{5}{|c|}{ Attitude } \\
\hline & $\begin{array}{l}\text { Strongly } \\
\text { agree }\end{array}$ & Agree & Moderate & Disagree & $\begin{array}{l}\text { Strongly } \\
\text { disagree }\end{array}$ \\
\hline $\begin{array}{l}\text { I know and understand how to check my own prog- } \\
\text { ress in this course }\end{array}$ & $13 \%$ & $70 \%$ & $17 \%$ & 0 & 0 \\
\hline $\begin{array}{l}\text { I have a clear idea why I need to study this course } \\
\text { (translation) online }\end{array}$ & $37 \%$ & $40 \%$ & $17 \%$ & $6 \%$ & 0 \\
\hline $\begin{array}{l}\text { The lecturer should motivate me in this translation } \\
\text { course }\end{array}$ & $37 \%$ & $60 \%$ & $3 \%$ & 0 & 0 \\
\hline $\begin{array}{l}\text { Doing translation even without my lecturer supervi- } \\
\text { sion is important for developing good language skills }\end{array}$ & $27 \%$ & $57 \%$ & $10 \%$ & 0 & 0 \\
\hline $\begin{array}{l}\text { I often practice translation when it is not the time for } \\
\text { online learning }\end{array}$ & $13 \%$ & $54 \%$ & $27 \%$ & $6 \%$ & 0 \\
\hline
\end{tabular}

thesis as their achievement.

Learners ability to define content and progression

Learners ability to define content significantly contributes to their initiative to look for resources. Either way, their dependability to lecturer would be still high. The learners' response on this aspect can been in Table 2.

The response above reveals that there is evenly distribution of students' ability in defining content, where almost half of them agree that they do not need lecturers' help every time (33\%). On the other hand, $47 \%$ respondents still need frequent help from lecturers despite the fact that all respondents agree that seeing the progress they make is very important (100\%). This means, learners are still lacking in taking initiative to define the content that they need, looking for sources on their own. It is also proven by the data that majority of the students tend to wait feedbacks from the lecturer to see how far they are progressing. On the contrary, the response from last item bring uniqueness to this study because it reflects students not only hoping for feedbacks, but also utilize technologies that they are familiar with to check their progression. Looking at this ambiguity, the researcher confirms that through interview to the subjects.

The students' response in this questionnaire is also supported by the results of interview in this regard. This answer a question why respondents wait for feedbacks but also check their progress themselves. Even though the data reveals that they check their progression themselves through technologies available regularly, the interview shows that the use of the technologies that they equipped with is still not optimal. The use of technologies is limited to checking pronunciation through website and using a skype call to share and discuss with friends. That is why confirmation from lecturers is needed by learners to have better checking and progression. It is also necessary to state that feedbacks from lecturer also triggers their motivation to progress even more. This is in line with Yu et al., (2020) who found out that feedbacks, regardless the types of it has a positive influence toward students motivation and engagement. The primary cause of it is students tend to seek for an approval from their teachers which one form of it is feedbacks (Panisoara et al., 2015)

\section{The ability to select method used in learning}

The result of the questionnaire for this aspect is provided in Table 3.

There are a number of methods that can be conducted by autonomous learning, yet the most important aspect is to be responsible with their own learning. Based on the results from questionnaire, the majority of the learners tend to rely on the lecturers' instructional method to teach them (93\%). On the other hand, learners 
Table 5. Learners' response in conducting self evaluation

\begin{tabular}{|c|c|c|c|c|c|}
\hline \multirow[t]{2}{*}{ Items } & \multicolumn{5}{|c|}{ Attitude } \\
\hline & $\begin{array}{l}\text { Strongly } \\
\text { agree }\end{array}$ & Agree & Moderate & Disagree & $\begin{array}{l}\text { Strongly } \\
\text { disagree }\end{array}$ \\
\hline $\begin{array}{l}\text { I have my own ways of testing how much I have } \\
\text { learned }\end{array}$ & $17 \%$ & $47 \%$ & $30 \%$ & $6 \%$ & 0 \\
\hline I like to look for solutions to my problems by myself & $13 \%$ & $67 \%$ & $20 \%$ & 0 & 0 \\
\hline I know when I have made an error in translation & $3 \%$ & $57 \%$ & $20 \%$ & $7 \%$ & $3 \%$ \\
\hline I like to wait for feedbacks from my lecturer & $20 \%$ & $77 \%$ & 0 & 0 & $3 \%$ \\
\hline $\begin{array}{l}\text { I often test myself in front of mirror or computer } \\
\text { and any other media to assess myself }\end{array}$ & $30 \%$ & $44 \%$ & $23 \%$ & $3 \%$ & 0 \\
\hline
\end{tabular}

admit that they can find the best way to learn a course subject like utilizing technologies that they are familiar with. The data also reveal that learners have various opinion on the amount of task given by the lecturers where $40 \%$ of the respondents argue that it is enough, yet the other $37 \%$ feel it should be more.

Aside from the questionnaire, the data from interview affirms that even though learners are equipped with technologies to practice, but the condition of the outbreak forces them to save their internet package since online class already spend much of it. This leads them to watch English movies that they have downloaded and try to practice from it.

Regarding the amount of task as shown above, some learners admit that they think the amount of the task is enough since they also need to focus on helping their parents work for saving this bad economic situation. In addition, a sudden change to total remote learning in this outbreak makes them unable to adapt as quick as expected. Thus, having them to work with more assignment will make them unable to manage their time.

\section{Learners level of understanding to monitor the procedure of acquiring knowledge}

The results from questionnaire above signifies that learners have their own way to monitor the procedure of acquiring knowledge. It can be seen from the statement that they know how to check their own progress in this course (83\%). Learners are also well aware of the importance of being independent in learning (84\%), and acquire knowledge without depending on the lecturer by doing self-practice when it is not the time for online learning (67\%).

According to the result of the interview, keep motivating learners encourage them to build consistency in learning and focus to reach the goal that they have set. One of the ways to keep the consistency is by practicing whenever it is not the time for online course. Some learners state that they have friends from abroad to help them practicing, some others use any kinds such as movies, songs, and news on TV.

\section{Learners ability to conduct self-evaluation}

One of the success of autonomous learning is based on learners' ability evaluate themselves. The researchers administer questionnaire as well on this aspect. The result can be seen in Table 5 .

Every individual must have their own way to evaluate themselves, and the result of the questionnaire shows that the majority of the learners have been aware of it (64\%). In the process of evaluation, learners normally find some problems that needs to be solved. An autonomous learner will do a deep checking and try to find solution independently. Thus it is reflected that most of the learners have tried to find solutions for their problems on their own (80\%). However, the needs for feedback is also important because learners wish to 
have confirmation whether the result of their self-evaluation is correct.

The result of the interview also finds out that learners have various ways to evaluate themselves, one of which is practicing in front of the mirror. This way, according to them, can build their confidence in learning as well as noticing their gesture while practicing. Another way that some learners mention is by asking their friends to be a rater for them. This way enables them to have an open discussion due to the closeness of the relationship they possess.

Looking at the findings, the condition of the pandemic really forces students to have a rapid change of learning method from classical to remote learning. A sudden change in learning requires learners to be more independent in learning. This is in line with the findings from Wong (2013) who stated that independent learning in higher education is appropriate to be done because learners will face further continuous development that urge them to be independent.

The findings in this study are also in line with Hafner and Miller (2011), and Lengkanawati (2017) findings in regards that there is misconception to some parties that autonomous learning means learners are able to learn without support at all. In fact, they need teacher support to keep their consistency, look for feedbacks, and confirming their own ways of evaluation. Additionally, the findings where learners are able to define the content of learning is in line with findings from Masouleh \& Jooneghani (2012). They find out that learners' ability to define the content of knowledge that they want to pursue supports theory of constructivism. It emphasizes that rather than internalizing or discovering objective knowledge, individuals are able to reconstruct their experience. This further leads to more effective learning since knowledge cannot be only taught but also constructed.

\section{Conclusion}

In order to optimize the learning process, it is necessary for students to foster their autonomy to minimize the impact and ineffectiveness of remote learning. It is also essential to measure the learning capacity of learners before conducting any necessary matter to promote their autonomy. The findings from this study show that students' current level of autonomy varies. Learners are quite self-directed in the aspects of defining content and progression, monitor the procedure of acquiring knowledge, and doing self-evaluation. Meanwhile, the aspects of setting objectives and selecting method to learn need to be improved.

It is highly recommended for prospective studies in regards to autonomy and instructional strategy to conduct further research on this, particularly in this pandemic situation where optimization of learning is a must despite all boundaries that challenge both learners and educators.

\section{References}

Abidah, A., Hidaayatulaah, H., Simamora, R., Fehabutar, D., \& Mutakinati, I. (2020). The impact of Covid-19 to Indonesian education and its relation to the philosophy of "merdeka belajar". Studies in Philosophy of Science and Education, 1(1), 38-49. doi:10.46627/sipose.v1i1.9

Aini, Q., Budiarto, M., Putra, P. O. H., \& Rahardja, U. (2020). Exploring E-learning Challenges During the Global COVID-19 Pandemic: A Review. Jurnal Sistem Informasi, 16(2), 57-65. https:// doi.org/10.21609/jsi.v16i2.1011

Aji, R. H. (2020). Dampak covid-19 pada pendidikan di Indonesia: sekolah, keterampilan, dan proses pembelajaran. Salam Jurnal Sosial \& Budaya Syar-i, 7(5), 395-402. doi:10.15408/sjsbs. v7i5.15314 
Alvarez, A. V. (2020). he phenomenon of learning at a distance through emergency remote teaching amidst the pandemic crisis. Asian Journal of Distance Education, 15(1), 144-153. doi:10.5281/ zenodo.3881529

Basilaia, G., \& Kvavadze, D. (2020). Transition to online education in schools during a SARS-coV-2 coronavirus(COVID-19) pandemic in Georgia. Pedagogical Research, 5(4), 1-9. doi:10.29333/pr/7937

Benson, P. (2001). Teaching and researching autonomy in language learning. Harlow: Pearson Education Limited.

Brasier, D. J., Melville, M., Hershock, C., \& Rule, G. (2019). Pairing practice and feedback with animations optimizes student learning in online module. Journal of Computer Assisted Learning, 35(6), 782-793. doi:10.1111/jcal.12388

Dafei, D. (2007). An exploration of the relationship between learner autonomy and English proficiency. Asian EFL Journal, 1-23.

Dhawan, S. (2020). Online learning: a panacea in the time of covid-19 crisis. Journal of Educational Technology Systems, 49(1), 5-22. doi:10.1177/0047239520934018

Dubey, P., \& Pandey, D. (2020). Distance learning in higher education during pandemic: challenges and opportunities. The International Journal of Indian Psychology, 8(2), 43-46. doi:10.25215/0802.204

Finch, A. (2000). A formative evaluation of a task based EFL programme for Korean University students. Manchester : Manchester University.

Genc, G. (2015). Autonomous learning capacity of EFL student teachers. International Journal of Languages' Education and Teaching, 3(2), 23-42.

Gharti, L. (2019). Self-directed learning for learner autonomy: Teachers' and students' perception. Journal of NELTA Gandaki, 1(1), 62-73.

Gillett-Swan, J. (2017). The challenges of online learning. Journal of Learning Design, 10(1), 20-30. doi:10.5204/jld.v9i3.293

Hafner, C., \& Miller, L. (2011). Fostering learner autonomy in English for science: A collaborative digital video project in a technological learning environment. Language Learning and Technology Journal, 15(3), 68-86. doi:10125/44263

Lengkanawati, N. (2017). Learner autonomy in the Indonesian EFL settings. Indonesian Journal of Applied Linguistics, 17(3), 222231. doi:10.17509/ijal.v6i2.4847

Littlewood, W. (1996). “Autonomy: An anatomy and framework. System, 24(4), 427-435.

Liu, H. j. (2015). Learner autonomy: The role of motivation in foreign language learning. Journal of Language Teaching and Research, 6(6), 1165-1174. doi:10.17507/ jltr.0606.02

Masouleh, N. S., \& Jooneghani, R. B. (2012). Autonomous learning: A teacher-less learning. Procedia Social and Behavioral Science, 55, 835-842. doi:10.1016/j. sbspro.2012.09.570

Mclaughlin, T. (2017). Diverse delivery methods and strong psychological benefits: a review of online formative assessment. Journal of Computer Assisted Learning, 33(6), 562-574. doi:10.1111/ jcal. 12200

Meyer, D. (2001). The measurement of intentional behavior as a prerequisite to autonomous learning. Doctoral Dissertation: George Washington University.

Mishra, L., Gupta, T., \& Shree, A. (2020). Online teaching-learning in higher education during lockdown period of COVID-19 pandemic. International 
Journal of Educational Research Open, 1,100012.https://doi.org/10.1016/j. ijedro.2020.100012

Muthuprasad, T., Aiswarya, S., Aditya, K. S., \& Jha, G. K. (2021). Students' perception and preference for online education in India during COVID -19 pandemic. Social Sciences \& Humanities Open, 3(1),100101.https://doi.org/10.1016/j. ssaho.2020.100101

Myartawan, I. P., Latief, M. A., \& Suharmanto. (2013). The correlation between learner autonomy and English proficiency of Indonesian efl college learners. TEFLIN Journal, 24(1), 63-81.

$\mathrm{Ni}$, E. (2020). Research on the autonomous learning mode in the environment of computer network technology. Journal of Physics, 1578, 1-5. doi:10.1088/1742$6596 / 1578 / 1 / 012030$

Nugroho, A., Ilmiani, D., \& Rekha, A. (2021). EFL Teachers' Challenges and Insights of Online Teaching amidst Global Pandemic. Metathesis: Journal of English Language, Literature, and Teaching,4(3),277.https://doi. org/10.31002/metathesis.v4i3.3195

Onyema, E. M., Eucheria, N. C., Obafemi, F. A., Sen, S., Atonye, F. G., Sharma, A., \& Alsayed, A. O. (2020). Impact of coronavirus pandemic on education. Journal of Education and Practice, 11(13), 108-121. doi:10.7176/JEP/11-13-12

Padmadewi, N. N. (2016). Techniques of promoting autonomous learning in the classroom. Journal of Education and Sciences, 3, 45-52.

Panisoara, G., Duta, N., \& Panisoara, I.O. (2015). The Influence of Reasons Approving on Student Motivation for Learning. Procedia -Social and Behavioral Sciences, 197, 1215-1222.https://doi. org/10.1016/j.sbspro.2015.07.382

Ponton, M. K. (2018). Learner autonomy profile: An estimation of normative statistics for nontraditional adults in the united states. International Journal of Education and Social Science Research, 1(6), 1-10.

Ponton, M. K., \& Rhea, N. E. (2006). Autonomous learning from a social cognitive perspective. New Horizons in Adult Education and Human Perspective, 20(2), 38-49.

Purwanto, A., Pramono, R., Ashari, M., Santoso, P. B., WIjayanti, L. M., Hyun, C. C., \& Putri, R. S. (2020). Studi eksploratif dampak pandemi covid-19 terhadap proses pembelajaran online di sekolah dasar. Journal of Education, Psychology and Counseling, 2(1), 1-12.

Scherer, R., Howard, S. K., Tondeur, J., \& Siddiq, F. (2021). Profiling teachers' readiness for online teaching and learning in higher education: Who's ready? Computers in Human Behavior, 118,106675.https://doi. org/10.1016/j.chb.2020.106675

Tran, T. Q., \& Duong, T. M. (2020). Efl learners' perception of factors influencing learner autonomy development. Kasetsart Journal of Social Sciences, 41, 194-199. doi:10.1016/j.kjss.2018.02.009

Üstünlüoğlu, E. (2009). Autonomy in language learning: Do students take responsibility for their learning? Journal of Theory and Practice in Education, 5(2), 148-169.

Wang, H., Pi, Z., \& Hu, W. (2018). The instructor's gaze guidance in video lectures improves learning. Journal of Computer Assisted Learning, 35(1), 4250. doi:10.1111/jcal.12309

Wong, I. L. (2013). Developing independent learning skills for postgraduate students through blended learning environment. Journal of Cases on Information Technology, 15(1), 36-50. doi:10.4018/ jcit.2013010103

Xhaferi, B., \& Xhaferi, G. (2011). Developing 
learner autonomy in higher education in Macedonia. Procedia Social and Behavioral Sciences, 11, 150-154. doi:10.1016/j.sbspro.2011.01.051

Yu, S., Jiang, L., \& Zhou, N. (2020). Investigating what feedback practices contribute to students' writing motivation and engagement in Chinese EFL context: A large scale study. Assessing Writing, 44, 100451. https://doi.org/10.1016/j. asw.2020.100451

Zaharah, Kirilova, G. I., \& Windarti, A. (2020). Impact of corona virus outbreak towards teaching and learning activities in Indonesia. Salam Journal of social and culture, 7(3), 269-282. doi:10.15408/ sjsbs.v7i3.15104 